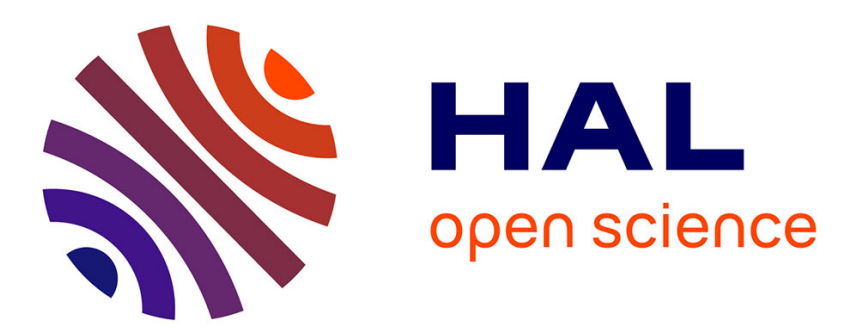

\title{
Corrosion mechanisms of $\mathrm{ZrO} 2-\mathrm{Y} 2 \mathrm{O} 3$ thermal barrier coatings in the presence of molten middle-east sand
}

\author{
D. de Wet, R. Taylor, F. Stott
}

\section{To cite this version:}

D. de Wet, R. Taylor, F. Stott. Corrosion mechanisms of ZrO2-Y2O3 thermal barrier coatings in the presence of molten middle-east sand. Journal de Physique IV Proceedings, 1993, 03 (C9), pp.C9-655C9-663. 10.1051/.jp4:1993969 . jpa-00252410

\section{HAL Id: jpa-00252410 https://hal.science/jpa-00252410}

Submitted on 1 Jan 1993

HAL is a multi-disciplinary open access archive for the deposit and dissemination of scientific research documents, whether they are published or not. The documents may come from teaching and research institutions in France or abroad, or from public or private research centers.
L'archive ouverte pluridisciplinaire HAL, est destinée au dépôt et à la diffusion de documents scientifiques de niveau recherche, publiés ou non, émanant des établissements d'enseignement et de recherche français ou étrangers, des laboratoires publics ou privés. 


\title{
Corrosion mechanisms of $\mathrm{ZrO}_{2}-\mathrm{Y}_{2} \mathrm{O}_{3}$ thermal barrier coatings in the presence of molten middle-east sand
}

\author{
D.J. de Wet( $\left.{ }^{\star}\right)$, R. Taylor and F.H. Stott
}

Corrosion \& Protection Centre and Materials Science Centre, UMIST, Manchester, U.K.

\begin{abstract}
The deposition of mineral debris in the turbine sections of various jet engines occurred after operation on Middle-East routes. Plasma sprayed $\mathrm{ZrO}_{2}-\mathrm{Y}_{2} \mathrm{O}_{3}$ thermal barrier coatings were aged with sand samples from several Middle-East locations at temperatures of 1200 to $1500{ }^{\circ} \mathrm{C}$. At temperatures above $1400^{\circ} \mathrm{C}$, the molten sand formed glassy silicate debris that penetrated the ceramic coating completely, resulting in the absorption of $\mathrm{ZrO}_{2}$ and $\mathrm{Y}_{2} \mathrm{O}_{3}$ into the silicate. Two corrosion mechanisms were identified, determined by the amount of calciumbased minerals in the sand.
\end{abstract}

\section{Introduction.}

Deposition of abnormal contaminants in the turbine sections of jet engines was experienced during operation on Middle-East routes [1]. Examination of the aerofoil pressure surface of high pressure turbine blades (Fig. 1) revealed the presence of two types of deposits. The first consisted of a thin, smooth, pink-brown deposit present to varying degrees over most of the turbine blade surfaces, and was an anhydride, calcium sulphate $\left(\mathrm{CaSO}_{4}\right)$, originating from the ingestion of gypsum $\left(\mathrm{CaSO}_{4} \cdot 2 \mathrm{H}_{2} \mathrm{O}\right)$ as a mineral dust. The second consisted of a much thicker light-brown deposit with a rough surface, and was a complex calcium-magnesium silicate, with a structure relating closely to the mineral, diopside $\left(\mathrm{CaMg}\left(\mathrm{SiO}_{3}\right)_{2}\right)$. This compound was believed to form during fusion above $1250^{\circ} \mathrm{C}$ in the combustion chamber as the reaction product of several minerals unique to this area.

Adhesion of the silicate to the blade was influenced by several factors, and occurred most probably only whilst the silicate was in the molten or semi-molten state, controlled by the melting point of the silicate and the gas temperature. A strong correlation was apparent between areas of deposition and the surface temperature of the blade. Comparison of the deposited HP turbine blades of affected engines with their thermal paint diagrams suggested that adhesion of the silicate may in general, only occur in areas on the blade above a fixed temperature. It is not known how such deposited contaminants will affect the service lives of thermal barrier coated components.

\section{Experimental procedure.}

Sand samples were obtained from several Middle-East locations, namely Doha, Dubai, Abu

$\left.{ }^{\star}\right)$ Present address: Division of Materials Science and Technology, CSIR, P O Box 395, Pretoria, 0001 , South Africa. 


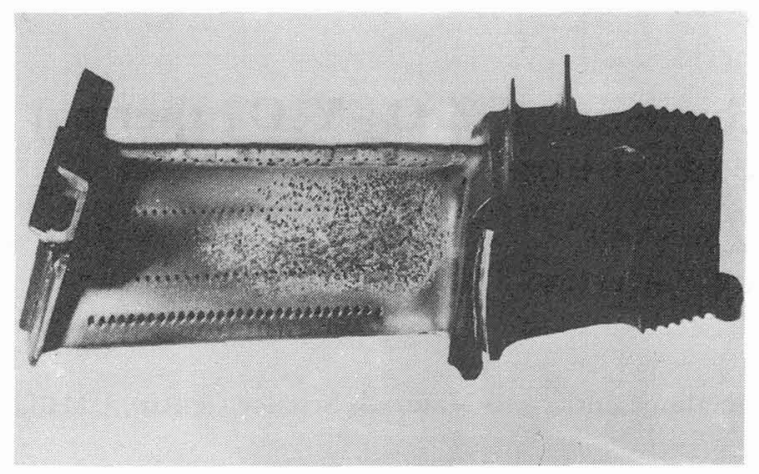

Fig. 1. - Silicate deposition on the aerofoil pressure surface of a civil HP turbine blade after MiddleEast operation.

Dhabi and Bahrain airports in the Persian Gulf region as well as Sinaiyah in western Saudi Arabia. The samples were characterized by means of X-ray diffraction (XRD), energy dispersive X-ray analysis (EDX), and differential thermal analysis (DTA).

Free standing plasma sprayed $\mathrm{ZrO}_{2}-8$ wt $\% \mathrm{Y}_{2} \mathrm{O}_{3}$ thermal barrier coated specimens, with thicknesses of 200-300 $\mu \mathrm{m}$, were prepared by dissolving the nickel-based substrate. The thin ceramic specimens were aged with small amounts of each of the sand samples at temperatures of 1200 to $1500^{\circ} \mathrm{C}$ for durations varying between 1 and $120 \mathrm{~h}$. The aged specimens were air quenched to retain the high temperature phases.

A series of simple silicate debris with $\mathrm{CaO}$ contents increasing from zero to approximately $60 \mathrm{wt} \%$ (Tab. I) was produced in a laboratory furnace. Hot-pressed, monolithic $\mathrm{ZrO}_{2}-14 \mathrm{wt} \%$ $\mathrm{Y}_{2} \mathrm{O}_{3}$ discs were aged with the silicate glasses/debris for $1 \mathrm{~h}, 71 \mathrm{~h}$ and $120 \mathrm{~h}$ at $1500^{\circ} \mathrm{C}$.

Table I. - Composition of silicate glasses/debris.

\begin{tabular}{|c|c|c|c|c|c|c||}
\hline \multirow{2}{*}{ oxide } & \multicolumn{6}{|c|}{ Composition of Selected Glass/Debris (wt\%) } \\
& 4 & 7 & 8 & 9 & $9 A$ & $9 B$ \\
\hline \hline CaO & 10.4 & 20.2 & 27.1 & 35.1 & 49.3 & 59.3 \\
$\mathrm{SiO}_{2}$ & 82.9 & 71.1 & 62.5 & 53.9 & 41.5 & 32.1 \\
$\mathrm{Na}_{2} \mathrm{O}$ & 6.7 & 8.8 & 10.4 & 10.9 & 9.3 & 8.7 \\
\hline
\end{tabular}

\section{Results and discussion.}

3.1 ANALYSES OF MIDDLE-EAST SAND. - Visual examination of the sand samples showed that each consisted of non-homogeneous mixtures of various phases, with variations in particle size, texture and colour. XRD, EDX and DTA analyses showed that the minerals common 
to all the samples were quartz $\left(\alpha-\mathrm{SiO}_{2}\right)$, calcite $\left(\mathrm{CaCO}_{3}\right)$, dolomite $\left(\mathrm{CaMg}\left(\mathrm{CO}_{3}\right)_{2}\right)$ and the feldspar silicates albite $\left(\mathrm{NaAlsi}_{3} \mathrm{O}_{8}\right)$ and microcline $\left(\mathrm{KAlSi}_{3} \mathrm{O}_{8}\right)$, with the Doha sample exhibiting a dominant presence of gypsum $\left(\mathrm{CaSO}_{4} \cdot 2 \mathrm{H}_{2} \mathrm{O}\right)$ (Tab. II). The samples can be classified into three categories:

a) Sinaiyah sand, consisting mainly of quartz and feldspar silicates; b) Bahrain, Dubai and Abu Dhabi sand, with a strong presence of quartz, calcite and dolomite; and c) Doha sand, consisting mainly of gypsum, with a very low presence of quartz.

Table II. - X-ray diffraction analyses of Middle-East sand samples; $v s=$ very strong, $s=$ strong, $m=$ medium, $v w=$ very weak.

\begin{tabular}{|c|c|c|c|c|c|}
\hline Mineral & sinaiyah & Bahrain & Dubai & $\begin{array}{c}\text { Abu } \\
\text { Dhabi }\end{array}$ & Doha \\
\hline $\begin{array}{l}\text { Quartz } \\
\alpha-\mathrm{SiO}_{2} \\
\text { Calcite } \\
\mathrm{CaCO}_{3} \\
\text { Aragonite } \\
\mathrm{CaCO}_{3} \\
\text { Dolomite } \\
\mathrm{CaMg}_{\left(\mathrm{CO}_{3}\right)_{2}} \\
\text { Gypsum } \\
\text { CaSO } \\
\text { Albite } 2 \mathrm{H}_{2} \mathrm{O} \\
\mathrm{NaAlSi}_{3} \mathrm{O}_{8} \\
\text { Microcline } \\
\text { KAlSi } \mathrm{O}_{8} \\
\text { Diopside } \\
\text { CaMg }\left(\mathrm{SiO}_{3}\right)_{2}\end{array}$ & $\begin{array}{l}- \\
\mathrm{w} \\
- \\
\mathrm{m} \\
\mathrm{m} \\
-\end{array}$ & $\begin{array}{c}\text { vs } \\
w / m \\
m \\
w / m . \\
- \\
w \\
w \\
w / m\end{array}$ & $\begin{array}{l}\text { s } \\
\text { vs } \\
- \\
\text { w } \\
- \\
\text { w } \\
\text { w } \\
-\end{array}$ & $\begin{array}{c}\text { VS } \\
\text { s } \\
- \\
\text { W } \\
- \\
\text { m/s } \\
\text { w } \\
-\end{array}$ & $\begin{array}{l}\text { w } \\
\text { w } \\
- \\
\text { m } \\
\text { vs } \\
- \\
- \\
-\end{array}$ \\
\hline
\end{tabular}

Chemical interactions between the ingested sand and the thermal barrier coatings are believed to occur only when the sand adheres to the hot blade surface, and, therefore, only when the sand is in the molten or semi-molten state. During ageing of sand samples at $1200^{\circ} \mathrm{C}$, melting of the Sinaiyah sand initiated, while the other samples were still unmolten. XRD analyses indicated that the Sinaiyah sand glassified, while the unmolten sand samples consisted mainly of calcium oxide, magnesium oxide, quartz, cristobalite and various calcium silicates. The $\mathrm{CaO}$ and $\mathrm{MgO}$ were formed as a result of the dissociation of calcite, dolomite and gypsum, but the presence of calcium silicates indicated that fusion occurred between the minerals [2].

3.2 CORROSION OF THERMAL BARRIER COATINGS BY MOLTEN MIDDLE-EAST SAND. - - Microstructural damage was observed after ageing of plasma sprayed coatings with Sinaiyah sand at $1400^{\circ} \mathrm{C}$ and $1500^{\circ} \mathrm{C}$ (Fig. 2a). Chemical interactions between the ceramic and silicate occurred, and approximately $5 \mathrm{wt} \% \mathrm{Y}_{2} \mathrm{O}_{3}$ and $13 \mathrm{wt} \% \mathrm{ZrO}_{2}$ were absorbed into the silicate.

The molten silicate penetrated through the entire thickness of the coating, causing its break up. The ceramic parts adjacent to the silicate exhibited a much finer grain structure. EDX 


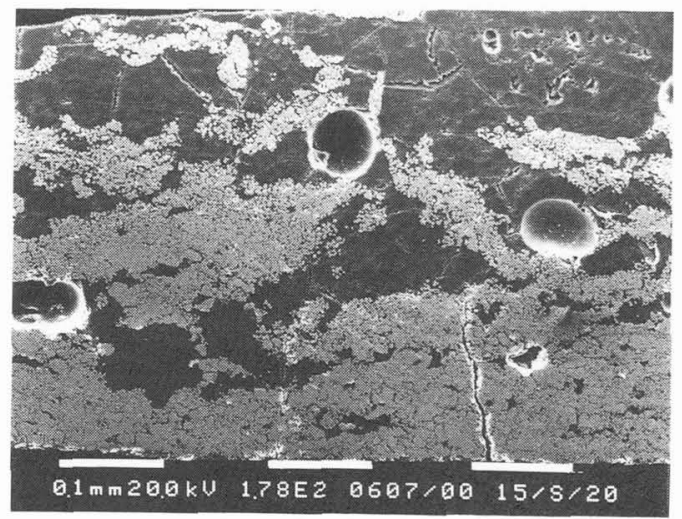

a)

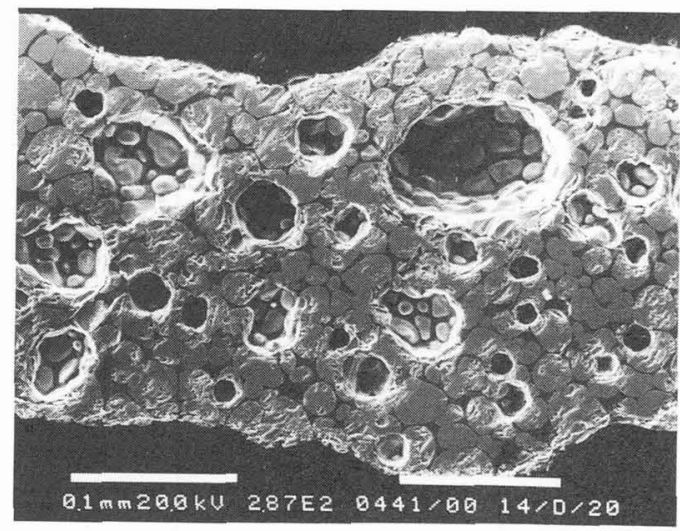

b)

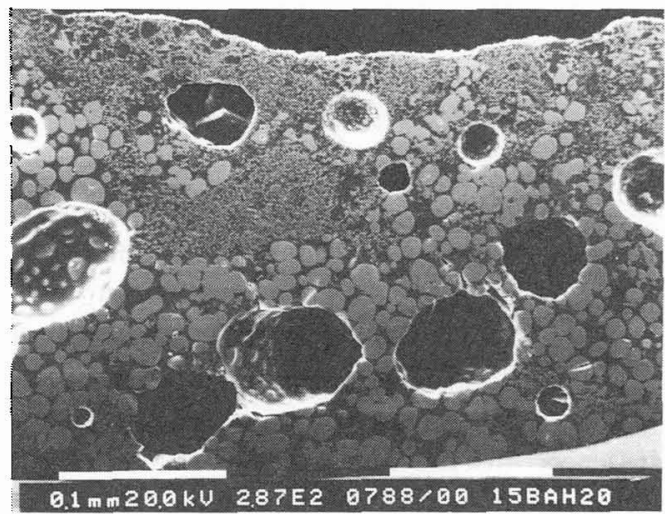

c)

Fig. 2. - Plasma sprayed $\mathrm{ZrO}_{2}-8 \mathrm{wt} \% \mathrm{Y}_{2} \mathrm{O}_{3}$ ceramic coating aged with: a) Sinaiyah sand at $1500{ }^{\circ} \mathrm{C}$ for $20 \mathrm{~h}$; b) Bahrain sand at $1400^{\circ} \mathrm{C}$ for $20 \mathrm{~h}$; c) Doha sand at $1400^{\circ} \mathrm{C}$ for $20 \mathrm{~h}$.

analyses indicated that the fine ceramic grains were depleted in the yttria stabiliser, with only 2 to $3 \mathrm{wt} \% \mathrm{Y}_{2} \mathrm{O}_{3}$ in the $\mathrm{ZrO}_{2}$ matrix, while the larger grains remained unaffected, with the 
original $8 w t \% \mathrm{Y}_{2} \mathrm{O}_{3}$ content. The leaching of the stabiliser initiated the disruptive tetragonal to monoclinic phase transformation during cooling, as confirmed by XRD.

Plasma sprayed coatings aged with sand from Bahrain, Dubai and Abu Dhabi exhibited similar corrosion mechanisms and microstructures (Fig. 2b). Two ceramic phases could be distinguished. As with the Sinaiyah sand, the upper part of the ceramic exhibited a fine grain structure, depleted in yttria. However, the strong presence of calcite and dolomite in the sand (Tab. II) caused severe grain boundary attack through the entire thickness of the coating, resulting in large, rounded ceramic grains with glassy silicate slag between them. The slag was mainly silica $\left(33 \mathrm{wt} \% \mathrm{SiO}_{2}\right)$ and calcia $(36 \mathrm{wt} \% \mathrm{CaO})$, although yttria $(7 \mathrm{wt} \%$ $\left.\mathrm{Y}_{2} \mathrm{O}_{3}\right)$ and zirconia $\left(21 \mathrm{wt} \% \mathrm{ZrO}_{2}\right.$ ) were absorbed during grain boundary attack.

Ageing of plasma sprayed coatings with Doha sand, consisting mainly of gypsum (Tab. II), caused diffusion of calcium from the calcium-rich silicate into the ceramic grains. The diffusion resulted in $4,2 \mathrm{wt} \% \mathrm{CaO}$ in the ceramic after $20 \mathrm{~h}$ at $1400^{\circ} \mathrm{C}$, and $7,4 \mathrm{wt} \% \mathrm{CaO}$ after $120 \mathrm{~h}$ at $1500^{\circ} \mathrm{C}$. Examination of the ceramic after $20 \mathrm{~h}$ at $1400^{\circ} \mathrm{C}$ (Fig. 2c) revealed grain boundary attack that caused large rounded grains with silicate between them. Yttria (4 wt\% $\mathrm{Y}_{2} \mathrm{O}_{3}$ ) and zirconia ( $14 \mathrm{wt} \% \mathrm{ZrO}_{2}$ ) were again absorbed into the silicate slag, but higher calcia $(41 \mathrm{wt} \% \mathrm{CaO})$ and lower silica $\left(30 \mathrm{wt} \% \mathrm{SiO}_{2}\right)$ contents were measured relative to the silicate formed during ageing with Bahrain sand.

Comparison of figures $2 \mathrm{a}, \mathrm{b}$ and $\mathrm{c}$ showed that the corrosion mechanisms are affected significantly by the presence of calcium-based minerals in the sand and, therefore, of calcium oxide in the silicate slag. The effect of $\mathrm{CaO}$ on the corrosion mechanisms was examined during ageing of monolithic $\mathrm{ZrO}_{2}-14 \mathrm{wt} \% \mathrm{Y}_{2} \mathrm{O}_{3}$ discs with silicate glasses/debris (Tab. I) having various calcium oxide contents.

3.3 EFFECT OF CALCIUM OXIDE ON THE CORROSION MECHANISMS. - The microstructures of the ceramic-silicate interfaces after ageing of the monolithic $\mathrm{ZrO}_{2}-14 \mathrm{wt} \% \mathrm{Y}_{2} \mathrm{O}_{3}$ discs at $1500^{\circ} \mathrm{C}$ for $71 \mathrm{~h}$ with the silicate debris (Tab. 1), are shown in figures 3a to e. After ageing with glass $4(10.4 \mathrm{wt} \% \mathrm{CaO})$, a finely structured ceramic layer occurred at the ceramic-silicate interface (Fig. 3a). This layer was depleted in yttria, with only $6 \mathrm{wt} \% \mathrm{Y}_{2} \mathrm{O}_{3}$. After ageing with glass 7 (20.3 wt\% CaO), a similar, but thinner, depleted layer was formed, while the depth of grain boundary attack increased (Fig. 3b). Round, ceramic protrusions on top of the depleted layer contained approximately $14 \mathrm{wt} \% \mathrm{Y}_{2} \mathrm{O}_{3}$, similar to the bulk composition.

The molten silicates attacked the ceramic along the grain boundaries and both yttria and zirconia went into solution [3], as indicated by EDX analyses of the silicate after ageing for $71 \mathrm{~h}$ (Tab. III). With only $15 \mathrm{wt} \%$ yttria in the ceramic matrix, the solubility limit of zirconia was reached before that of yttria, resulting in the redeposition of a ceramic layer, depleted in yttria, after only $1 \mathrm{~h}$ of ageing (Fig. 4a). An equilibrium between absorption and redeposition of zirconia was maintained, while silicate attack along grain boundaries, and consequently, yttria absorption, continued. After $71 \mathrm{~h}$ of ageing with glass 7 , the solubility limit of yttria was also reached, and large protrusions of a ceramic phase with the same composition as the bulk, were deposited onto the depleted layer (Fig. 4b).

During ageing with glass $8(27.1 \mathrm{wt} \% \mathrm{CaO})$, redeposition of a depleted layer did not occur, and it appeared as if the silicate penetrated the ceramic and "lifted" the surface layers (Fig. 3c). Little grain-boundary attack occurred after $1 \mathrm{~h}$ at $1500^{\circ} \mathrm{C}$, (Fig. 4b), although the silicate absorbed $22 \mathrm{wt} \% \mathrm{ZrO}_{2}$ and $10 \mathrm{wt} \% \mathrm{Y}_{2} \mathrm{O}_{3}$ from the ceramic during the short ageing cycle.

The depth of grain boundary attack increased marginally after ageing with glass $9(35.1 \mathrm{wt} \%$ $\mathrm{CaO}$ ) (Fig. 3d). Ageing with silicate debris having higher calcia contents (glass 9A - 49.3 wt\% $\mathrm{CaO}$ ) resulted in a significant increase in the depth of attack (Fig. 3e), while silicate from glass $9 \mathrm{~B}(59.3 \mathrm{wt} \% \mathrm{CaO})$ penetrated the ceramic thickness of $1 \mathrm{~mm}$. Simultaneously, the 


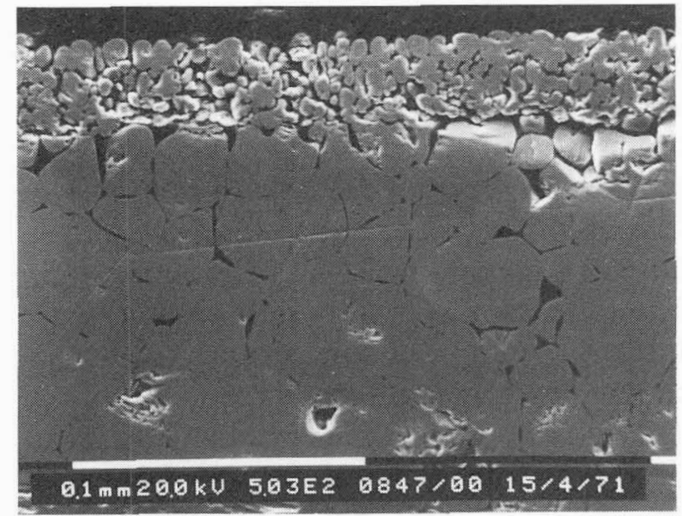

a)

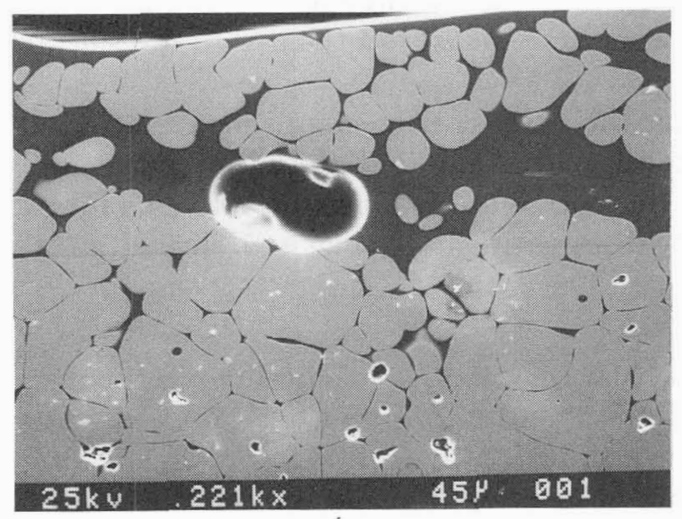

c)

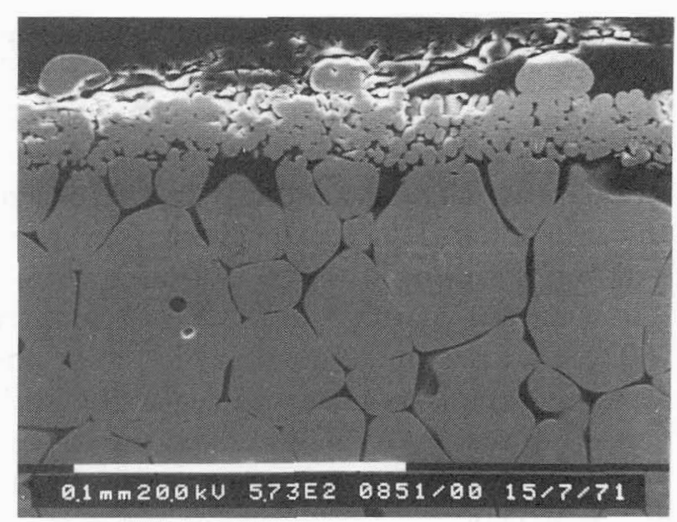

b)

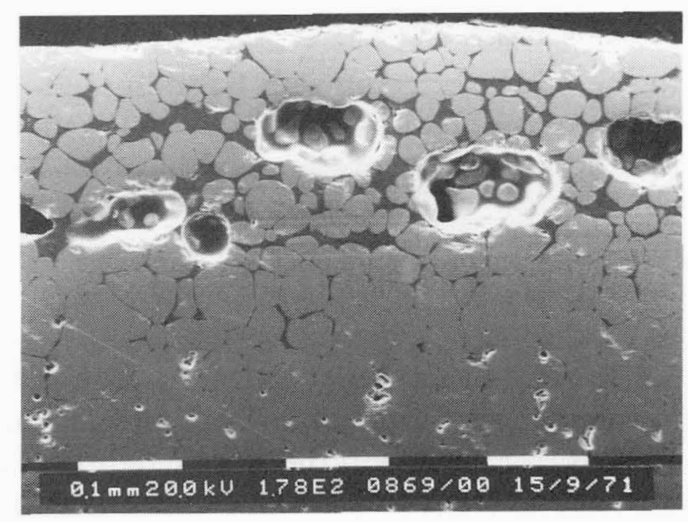

d)

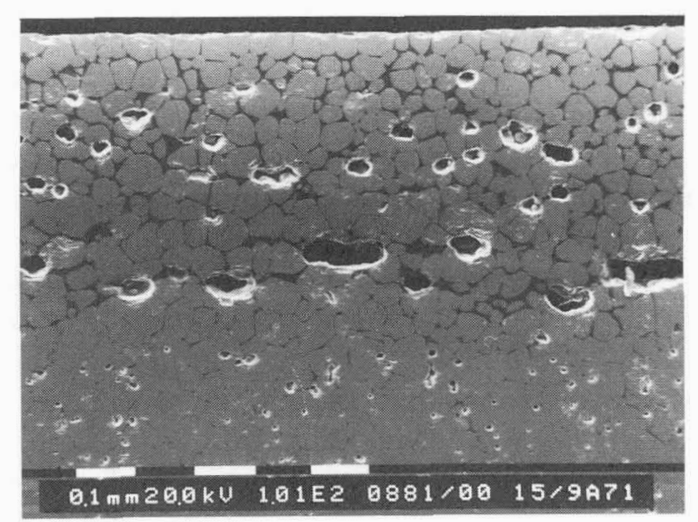

e)

Fig. 3. - Dense, monolithic $\mathrm{ZrO}_{2}-14 \mathrm{wt} \% \mathrm{Y}_{2} \mathrm{O}_{3}$ ceramic discs aged at $1500^{\circ} \mathrm{C}$ for $71 \mathrm{~h}$ with silicate debris containing: a) glass 4 ; b) glass 7 ; c) glass 8 ; d) glass 9 ; e) glass $9 \mathrm{~A}$. 
Table III. - Silicate composition after ageing of dense, monolithic $\mathrm{ZrO}_{2}-14$ wt\% $\mathrm{Y}_{2} \mathrm{O}_{3}$ discs with soda-lime glasses/debris at $1500^{\circ} \mathrm{C}$ for $71 \mathrm{~h}$.

\begin{tabular}{|c|c|c|c|c|c|c||}
\hline \multirow{2}{*}{ Oxide } & \multicolumn{6}{|c|}{ Silicate composition } \\
& Glass & Glass & Glass & Glass & Glass & Glass \\
& 4 & 7 & $\mathbf{8}$ & $\mathbf{9}$ & $\mathbf{9 B}$ \\
\hline \hline $\mathrm{CaO}$ & 6 & 12 & 15 & 17 & 26 & 32 \\
$\mathrm{SiO}_{2}$ & 62 & 53 & 49 & 48 & 42 & 39 \\
$\mathrm{Na}_{2} \mathrm{O}$ & 2 & 2 & 1 & 2 & - & - \\
$\mathrm{Y}_{2} \mathrm{O}_{3}$ & 11 & 13 & 14 & 15 & 16 & 12 \\
$\mathrm{ZrO}_{2}$ & 20 & 20 & 21 & 18 & 28 & 17 \\
\hline
\end{tabular}

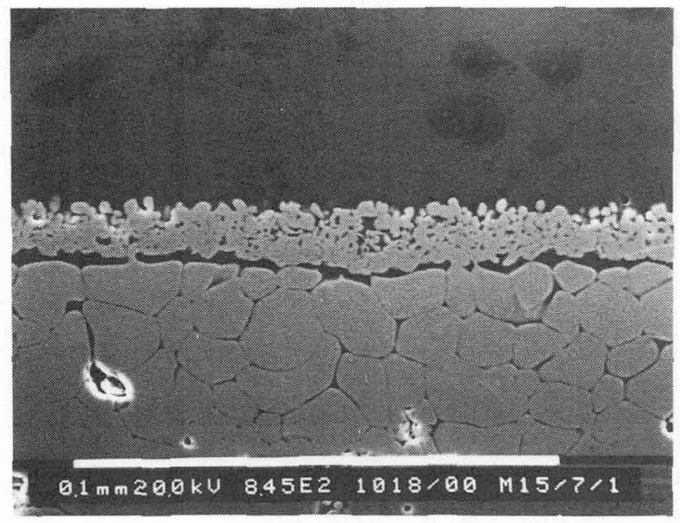

a)

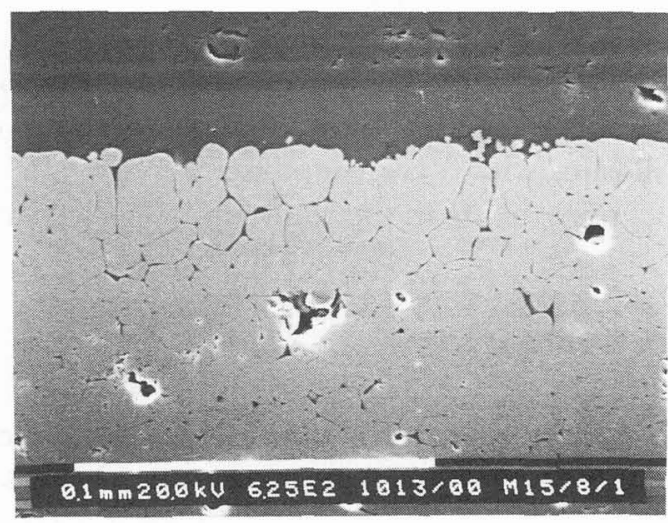

b)

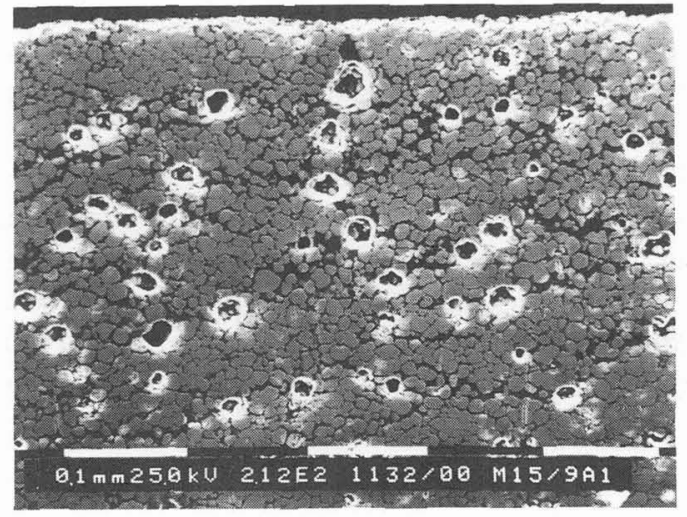

c)

Fig. 4. - Dense, monolithic $\mathrm{ZrO}_{2}-14 \mathrm{wt} \% \mathrm{Y}_{2} \mathrm{O}_{3}$ ceramic disc aged at $1500^{\circ} \mathrm{C}$ for $1 \mathrm{~h}$ with silicate debris containing: a) glass 7 ; b) glass 8 ; c) glass $9 \mathrm{~A}$. 
rate of grain-boundary attack increased with increased calcium oxide content to such an extent that, during ageing with glass $9 \mathrm{~B}$, the molten silicate penetrated the ceramic matrix without spreading over the entire surface, resulting in severe attack in the middle of the specimen, with the edges unaffected. The initial stages of this silicate attack exhibited rapid grain-boundary penetration and grain fragmentation (Fig. 4c). After the chemical reaction reached an equilibrium, grain growth occurred and, concurrently, diffusion of calcium into the ceramic ( $3 \mathrm{wt} \% \mathrm{CaO}$ after $120 \mathrm{~h}$ ).

The corrosion rate depends on the rate of transport of zirconia and yttria in the silicate, which is determined by their positions in the short-range order of the silicate glass. $\mathrm{ZrO}_{2}$ can act as either a glass-former, with a cation coordination number of 6 , or as an intermediate oxide, with a coordination number of 8 , while $\mathrm{Y}_{2} \mathrm{O}_{3}$ will enter the glass structure in the same way as $\mathrm{CaO}$, a modifier [4]. Modifying atoms move in interstitional regions and channels in the glass structure, and the rate of diffusion increases when the modifying content of a glass is increased, due to the break-up of the network structure on the addition of such atoms [5].

The rate of diffusional transport varied according to the composition of the original silicate/debris during ageing. In acidic silicates with a low modifier content (glasses 4 and 7), the absorbed $\mathrm{ZrO}_{2}$ entered the random network structure as an intermediate oxide. However, similar to the dual coordination of $\mathrm{TiO}_{2}$ in the $\mathrm{Na}_{2} \mathrm{O}-\mathrm{SiO}_{2}-\mathrm{TiO}_{2}$ system [6], basic silicates with a high modifier content (glasses $9,9 \mathrm{~A}$ and $9 \mathrm{~B}$ ) absorbed $\mathrm{ZrO}_{2}$ as a networkforming oxide in the random network structure.

\section{Conclusions.}

1) Molten Sinaiyah sand, with a low calcium-based mineral content, exhibited the same corrosion mechanism as acidic silicates. Yttria and zirconia were absorbed during grainboundary attack, but zirconia in excess of the solubility limit of the silicate, was redeposited as a monoclinic, fine grain structure depleted in yttria.

2) Molten Doha sand exhibited the same corrosion mechanism as basic silicates. This involved rapid grain boundary attack coupled with grain fragmentation during the initial stages; however, after equilibrium was reached, grain growth and calcium diffusion into the ceramic matrix occurred.

3) Molten sand from Bahrain, Dubai and Abu Dhabi exhibited a combination of the two corrosion mechanisms, with the presence of redeposited zirconia depleted in yttria generally in the upper half of the ceramic, where the silicate was originally deposited, while grain growth and calcium diffusion into the large, rounded ceramic grains occurred in the rest of the ceramic matrix. Similar microstructures were obtained after ageing of plasma sprayed $\mathrm{ZrO}_{2}-\mathrm{Y}_{2} \mathrm{O}_{3}$ coatings with intermediate silicate debris.

\section{Acknowledgements.}

Rolls Royce plc, Derby is thanked for providing the coatings, and the CSIR for financial support to DdW. 


\section{References}

[1] Toritz F.C., Thakker A.B., Gupta S.K., J. Am. Soc. Mech. Eng. 88-GT-279 (1988) 279.

[2] De Wet D.J., Stott F.H., TAYloR R., Proceedings of the 3rd International Conference on Advances in Coatings and Surface Engineering for Corrosion and Wear Resistance (Newcastle upon Tyne, UK, 11-15 May 1992).

[3] Weyl W. A., Marboe E.C., The Constitution of Glasses - A Dynamic Interpretation, Vol. 2, Part 2 (Interscience Publishers, New York, London, Sydney, 1967) p. 1161.

[4] VAN VLACK L.H., Physical Ceramics for Engineers (Addison-Wesley Publishing Company, Reading Massachusetts, 1964) p. 62.

[5] Kofstad P., High Temperature Corrosion (Elsevier Applied Science, London, New York, 1988) p. 78

[6] Weyl W.A., Marboe E.C., The Constitution of Glasses - A Dynamic Interpretation, Vol. 2, part 2 (Interscience Publishers, New York, London, Sydney 1967) p. 610. 